\title{
MEAT QUALITY PARAMETERS OF BROILER CHICKENS FED DIETS CONTAINING CHICORY (Cichorium intybus) VINASSE
}

\author{
PARÁMETROS DE CALIDAD DE CARNE DE POLLOS BROILER \\ ALIMENTADOS CON VINAZA DE ACHICORIA (Cichorium intybus)
}

\author{
Valeria Velasco ${ }^{1 *}$, Víctor Hugo Soto ${ }^{1}$, Pamela Williams s ${ }^{1}$ Jorge Campos ${ }^{1}$, Rita Astudillo ${ }^{1}$, Hernán \\ Rodríguez $^{1}$ \\ ${ }^{1}$ Department of Animal Sciences, Faculty of Agronomy, University of Concepción, P.O. Box 537, Chillán, \\ Chile. \\ *Corresponding author E-mail: vvelasco@udec.cl
}

\begin{abstract}
The decline in the availability of cereals and oilseeds has led to the study of different ingredients in animal feeding that do not affect meat quality. Chicory (Cichorium intybus) vinasse is a by-product of chicory processing, which could be used as a source of protein in animal diets. The aim of this study was to evaluate carcass yield and meat quality parameters of broiler chickens fed with chicory vinasse as a replacement for soybean meal during the fattening stage. A total of 320 broiler chickens and 5 treatments replacing soybean meal for chicory vinasse were used: 0 (T0), 25 (T1), 50 (T2), 75 (T3) and $100 \%$ (T4). Carcass yield, $\mathrm{pH}$, drip loss, color, composition and sensorial acceptance of meat were determined. Carcass yield ranged from 54.27 to $71.46 \%$, with a higher yield in T0 and T1 (P $\leq 0.05)$. The $\mathrm{pH}$ value was $5.79-6.23$; drip loss was $1.19-3.05 \%$; color difference $(\Delta \mathrm{E})$ ranged from 0.70 to 3.94 ; and the sensorial acceptance was high for the treatments including vinasse $(P>0.05)$. No significant differences $(\mathrm{P}>0.05)$ were observed in breast composition. However, there were significant differences $(P \leq 0.05)$ in lightness $\left(L^{*}\right)$ and composition of the thigh in T4 compared with T0. Therefore, the replacement of soybean meal for chicory vinasse in the diet of broiler chickens during fattening above $25 \%$ causes a decrease in carcass yield, while a $100 \%$ chicory vinasse replacement affects the lightness and chemical composition of the thigh.
\end{abstract}

Key words: breast, thigh, soybean meal, carcass yield, color, acceptance.

\section{RESUMEN}

La disminución de la disponibilidad de cereales y leguminosas ha llevado a evaluar diferentes ingredientes en alimentación animal que no afecten la calidad de la carne. La vinaza de achicoria (Cichorium intybus) es un subproducto del procesamiento de achicoria, la cual puede ser utilizada como fuente de proteína en dietas de animales. El objetivo de este estudio fue evaluar el rendimiento de canal y parámetros de calidad de carne de pollos broiler alimentados con vinaza de achicoria en reemplazo de harina de soya durante la etapa de engorda. Un total de 320 pollos broiler fueron usados, en 5 tratamientos de reemplazo de harina de soya por vinaza de achicoria: 0 (T0), 25 (T1), 50 (T2), 75 (T3) y 100\% (T4). Se determinó rendimiento de la canal, $\mathrm{pH}$, pérdidas por goteo, color, composición y aceptación sensorial de la carne. El rendimiento de la canal varió entre 54,27 y 71,46\%, con rendimientos mayores para T0 y T1 $(\mathrm{P} \leq 0,05)$. El $\mathrm{pH}$ fue de $5,79-6,23$, pérdidas por goteo de 1,19$3,05 \%$, diferencia de color $(\Delta \mathrm{E}) 0,70-3,94$ y la aceptación sensorial fue alta $(\mathrm{P}>0,05)$ para tratamientos que incluyeron vinaza. No se presentaron diferencias significativas $(P>0,05)$ en la composición de pechuga. Sin embargo, en el muslo (trutro) se presentaron diferencias significativas $(P \leq 0,05)$ en luminosidad $\left(L^{*}\right)$ y composición de T4 comparado con T0. Por lo tanto, el reemplazo de harina

Received: 24 January 2018. Accepted: 26 February 2018. 
de soya por vinaza de achicoria en dietas de pollos broiler durante la etapa de engorda sobre $25 \%$ causa una disminución del rendimiento de la canal y un reemplazo del $100 \%$ afecta la luminosidad y composición química del muslo (trutro).

Palabras clave: pechuga, muslo, trutro, harina de soya, rendimiento de canal, color, aceptación.

\section{INTRODUCTION}

Globally, the use of cereals and oilseeds has increased in the biofuel industry and therefore, the availability of these products is limited both for human and animal consumption (Arístegui, 2009). In addition, the high import prices of corn and soybean in the internal market has encouraged the use of new ingredients in animal feeding that decrease production costs (ODEPA, 2016). It is known that in broiler chicken production, feeding costs correspond to $59-70 \%$ of the total production cost (Trómpiz et al., 2010).

By-products or agricultural waste from processing industries could be used in animal feed (Díaz et al., 2003). Chicory vinasse (Nutrachic vinasse ${ }^{\circledR}$ ) is a dark viscous liquid obtained as a by-product of the processing of industrial chicory (Cichorium intybus) with significant water and protein content. Therefore, it would be an alternative for soybean meal replacement when used as feed supplement in animal diets, such as cattle and poultry.

In Chile, industrial chicory has been produced commercially since 2006, mainly in Biobío and Araucanía Regions. Since then, the cultivation after the stage of introduction and expansion has tended to remain at around 2,500 hectares (Traub, 2014). Chile ranks third in the world's exports of inulin extracted from chicory, with 938 tons and USD 46 million (FOB prices) in 2013 (Trómpiz et al., 2010).

On the other hand, the broiler chicken production reached 252.2 million units, being $95.6 \%$ of the total of poultry production. In the last two decades, the internal production of poultry meat has increased $119 \%$ at an annual average rate of $4 \%$. The greatest production period was 2013, with 680,571 tons, representing an increase of $0.9 \%$ compared to 2012. In 2014, the total production of poultry meat was 699,054 tons, of which $84.7 \%$ corresponded to broiler chicken meat (567,004 tons), $14.5 \%$ to turkey meat $(96,802$ tons), and $0.8 \%$ to hens (5,229 tons). The rest corresponded to other poultry meat, including ducks, geese, ostriches and others, with an annual production of 19.6 tons (Giacomozzi, 2015).

In recent decades, the poultry industry has undergone a major transformation and development in order to improve poultry meat quality and reach a higher acceptance by the consumers. The concept of meat quality is difficult to be defined due to the subjective nature of the features that are commercially important, such as: color, texture, juiciness and flavor (Beriain et al., 2000). Quality has been defined as all those desirable characteristics by consumers that both farmers and processing industries pursue to satisfy. The poultry industry has remained competitive due to its capacity to adapt to the changing needs and preferences of consumers. However, throughout the transformation of the carcass into commercial products, processing companies have faced several problems in terms of meat quality. These problems are related to characteristics of tenderness, color, water holding capacity (WHC) and cohesion capacity, which have been reported in chicken and turkey meat. Consumers perceive meat quality mainly in terms of safety, color, absence of off-odors, fat content and ease of preparation. Other important aspects are the conditions before slaughtering and lipid oxidation of meat, which can affect meat quality and consumer acceptability (Jiang et al., 2014). Certain attributes of meat quality could be affected by genetics, animal handling and slaughtering (Michel et al., 2015).

The objective of this study was to evaluate carcass yield and meat quality of broiler chickens fed chicory vinasse as a replacement of soybean meal during the fattening stage.

\section{MATERIALS AND METHODS}

\section{Description of the assay and treatments}

The study was carried out in the Faculty of Agronomy, University of Concepción, Chillán, Chile. A total of 20 pens with a surface of 1.69 $\mathrm{m}^{2}$ each equipped with a feeder and waterer were used. Room temperature was maintained in an average of $27^{\circ} \mathrm{C}$ through electric and gas heating, according to chickens' requirements (Estrada-Pareja et al., 2007). Light was provided 24 hours a day by means of $20 \mathrm{~W}$ tubes located at a height of $2.5 \mathrm{~m}$. A total of 320 unsexed Hybrid Ross broiler chickens vaccinated against avian bronchitis (Massachusetts I) were used. Diets were formulated according to the requirements for each productive stage (NRC, 1994). For the fattening stage, diets were formulated with corn, soybean meal, fishmeal, wheat bran, methionine, 
dicalcium phosphate, vitamins and minerals. Water and feed were offered ad libitum. From day 23 until the end of the assay, soybean meal was substituted by chicory vinasse (Cichorium intybus) according to the treatments, changing other ingredients in order to get diets that can be similar to isoenergetic diets in terms of content of digestible protein (Table 1). The nutritional composition of the chicory vinasse (Nutrachic vinasse $^{\circledR}$ ) is presented in Table 2. In total, 5 treatments with 4 replicates each were established (Table 1). Each pen was a replicate with 16 chickens (64 chickens per treatment). The control diet (T0) was prepared with soybean meal, while chicory vinasse replaced soybean meal in treatments T1, T2, T3 and T4 in 25, 50, 75 and $100 \%$, respectively. After the fattening period, the stunning of chickens were carried out by cervical dislocation and exsanguination (Monroe et al., 2003). One chicken per random replicate (4 chickens per treatment) was selected, and pectoral muscles and thighs of each were obtained. Meat was stored in sealed plastic bags and maintained refrigerated $\left(4^{\circ} \mathrm{C}\right)$ until analysis.

\section{Measurements}

Feed intake ( $\mathrm{g}$ chicken day $\left.^{-1}\right)$ : The feed offered daily $(\mathrm{g})$ was divided by the number of the chickens in each pen.

Carcass yield (Carcass weight live weight ${ }^{-1}$ ): Each selected broiler chicken was weighed at the slaughtering time and the chilled carcass weight was determined after $24 \mathrm{~h}$ (James et al., 2006).

pH: This parameter was measured immediately after slaughtering and after 24 hours in the dorsal muscle, using a portable pHmeter (Hanna Instruments ATC model HI 8424, Portugal) with penetration electrode calibrated with buffer solution at $\mathrm{pH} 4.0$ and 7.0.

Drip loss: This parameter was measured on samples of pectoral muscle. A piece of meat cut perpendicularly to the axis of the muscle was used, with a weight of $50 \mathrm{~g}$ and a thickness of $1.5 \mathrm{~cm}$. Meat was placed on a fine grid $\left(1 \mathrm{~cm}^{2}\right.$ of space) within sealed containers. Such containers were maintained in refrigeration $\left(4^{\circ} \mathrm{C}\right)$ during 48 $h$. Results were expressed in percentage of drip loss as a difference between initial weight $(24 \mathrm{~h}$ post mortem) and final weight ( $72 \mathrm{~h}$ post mortem) of raw meat (Otto et al., 2004).

Color: Samples of pectoral muscle and thigh were analyzed by a reflection colorimeter (Hunter Lab 45/0 Color Quest, Hunter Associates Laboratory, Inc. Reston, Virginia, USA), which measures the color coordinates of the CIELab space. Parameters such as chroma $\left(C^{*}\right)$, hue angle $(\mathrm{h})$ expressed in degrees $\left(0^{\circ}+a^{*}, 90^{\circ}+b^{*}, 180^{\circ}-a^{*}, 270^{\circ}-b^{*}\right)$, and color difference $(\Delta \mathrm{E})$ of the meat respect to the control were determined through the following

$$
\begin{aligned}
& C^{*}=\sqrt{\left(a^{* 2}+b^{* 2}\right)}, h=\arctan \left(\frac{b^{*}}{a^{*}}\right), \\
& \Delta E=\sqrt{\left(L_{1}^{*}-L_{2}^{*}\right)^{2}+\left(a_{1}^{*}-a_{2}^{*}\right)^{2}+\left(b_{1}^{*}-b_{2}^{*}\right)^{2}} \quad \text {, where }
\end{aligned}
$$

\begin{tabular}{|c|c|c|c|c|c|}
\hline & \multicolumn{5}{|c|}{ Treatments (diets) } \\
\hline & 0 (Control) & $1(25 \%)$ & $2(50 \%)$ & $3(75 \%)$ & $4(100 \%)$ \\
\hline \multicolumn{6}{|l|}{ Nutritional composition } \\
\hline Metabolizable energy $\left(\mathrm{kcal} \mathrm{kg}^{-1}\right)$ & 3,852 & 3,808 & 3,564 & 3,626 & 3,609 \\
\hline Protein $(\%)$ & 15.72 & 19.47 & 28.51 & 21.26 & 25.60 \\
\hline Digestible protein $(\%)$ & 18.29 & 18.64 & 18.48 & 18.34 & 17.83 \\
\hline \multicolumn{6}{|l|}{ Ingredients (kg $\left.1000 \mathrm{~kg}^{-1}\right)$} \\
\hline Corn grain & 684.0 & 645.0 & 614.0 & 581.0 & 543.0 \\
\hline Soybean meal & 230.0 & 172.5 & 115.0 & 57.5 & 0.0 \\
\hline Chicory vinasse & 0.0 & 57.5 & 115.0 & 172.5 & 230.0 \\
\hline Fishmeal & 60.0 & 70.0 & 70.0 & 70.0 & 60.0 \\
\hline Wheat bran & 0.0 & 30.0 & 62.0 & 96.0 & 134.0 \\
\hline Calcium carbonate $\left(\mathrm{CaCO}_{3}\right)$ & 14.0 & 15.0 & 14.0 & 15.0 & 14.0 \\
\hline Salt $(\mathrm{NaCl})$ & 2.0 & 2.0 & 2.0 & 2.0 & 2.0 \\
\hline Dicalcium phosphate & 8.0 & 6.0 & 6.0 & 5.0 & 5.0 \\
\hline Minerals* & 0.5 & 0.5 & 0.5 & 0.5 & 0.5 \\
\hline D. L. Methionine & 1.0 & 1.0 & 1.0 & 1.0 & 1.0 \\
\hline Vitamins $^{* *}$ & 0.5 & 0.5 & 0.5 & 0.5 & 0.5 \\
\hline
\end{tabular}

Table 1. Nutritional composition of the diets $\left(\mathrm{kg} 1000 \mathrm{~kg}^{-1}\right)$ of broiler chickens fed with chicory vinasse.

Diets formulated for broilers according to the National Research Council (NRC, 1994). "Minerals: mineral mixture constituted by $\mathrm{Cu}, \mathrm{Fe}, \mathrm{Zn}, \mathrm{Mn}$, Co. "Vitamin mixture: constituted by vitamins A, D, E, K, B2, B12, nicotinic acid, calcium pantothenate, folic acid, biothin, choline chloride and antioxidant. 
Table 2. Nutritional composition of chicory vinasse (Nutrachic vinaza $\left.{ }^{\circledR}\right)$ included in the diet of broilers.

\begin{tabular}{lc}
\hline Component & Content (\%)¥ \\
\hline Dry matter & 57.43 \\
Crude protein & 76.83 \\
Nitrogen-free extract & 14.42 \\
Crude ash & 8.61 \\
Ether extract & 0.14 \\
Crude fiber & 0.00 \\
\hline
\end{tabular}

$¥$ Percentage based on dry matter

$\mathrm{L}_{1}^{*}, \mathrm{a}_{1}{ }^{*}$ and $\mathrm{b}_{1}{ }^{*}$ are the color coordinates of the reference (control treatment) and $\mathrm{L}_{2}{ }^{*}, \mathrm{a}_{2}{ }^{*}$ and $\mathrm{b}_{2}{ }^{*}$ are the color coordinates of the sample (Konica Minolta, 2003).

Nutritional composition of chicken meat: A total of $50 \mathrm{~g}$ of pectoral muscle and $50 \mathrm{~g}$ of thigh per separate in each replicate were extracted in order to perform a proximal analysis using the following methods: proteins according to the Kjeldhal method (981.10); lipids, determined as the ether extract method (960.39); and minerals, through the determination of ashes (920.153) (AOAC, 1997).

Sensory analysis: Acceptance of color, aroma and total acceptance of the raw meat of the pectoral muscle was evaluated. This cut was used because homogeneous pieces can be obtained. An untrained sensory panel of 28 people was formed. The meat was randomly presented and identified by a randomly chosen 3-digit code. Each panelist evaluated 5 samples (one per treatment) and qualified the acceptance of the above-mentioned properties, through a 5-point hedonic scale: 1 (I dislike it very much), 2 (I dislike it), 3 (indifferent), 4 (I like it), and 5 (I like it very much) (Velasco et al., 2011).

\section{Experimental design and statistical analysis}

A randomized complete block design was used according to the location inside the room, with four blocks, each one with four pens (one replicate of each treatment). Data were subjected to analysis of variance (ANOVA) with 5\% significance and Duncan's test was applied in case of presenting difference between means, with 5\% significance. The assumptions of the variance were verified through modified Shapiro-Wilk test for normality and Levene's test for homogeneity of variance, both with $5 \%$ significance. For the evaluation of acceptance, a completely random design with 28 replicates was used, where each panelist was a replicate. A Kruskal - Wallis nonparametric ANOVA was used and Conover's test was applied as test of contrasts, both with $5 \%$ of significance. The software used in the study was Info-Stat@.

\section{RESULTS AND DISCUSSION}

Results of feed intake, carcass yield, $\mathrm{pH}$ and drip loss of chicken meat are presented in Table 3. Lower carcass yield was obtained with the increase in chicory vinasse in the diet, which could be due to the decrease in diet consumption. Treatments with higher carcass yields $(\mathrm{P} \leq$ 0.05 ) were $\mathrm{T} 0$ and $\mathrm{T} 1$, with $71.46 \%$ and $71.22 \%$, respectively. In this study, the treatment with the highest level of soybean meal replacement had the lowest carcass yield $(\mathrm{P} \leq 0.05)$.

During the period of meat aging, there are changes in pH (Velasco et al., 2011). According to Temprado (2005), $\mathrm{pH}$ of the muscle is closer to neutrality, in the first 3 to 4 hours after slaughter decreases to 6.17 (breast) and 6.40 (thigh), reaching final values of 5.70 (breast) and 5.90 (thigh) at 24 hours post mortem. In this study, $\mathrm{pH}$ values of chicken meat varied between 5.79 and 6.23 after slaughtering and decreasing in all treatments fluctuating between 5.66 and 5.78 at 24 hours post mortem. These results are similar to those reported in other studies (Qiao et al., 2002; Cori et al., 2014). No significant differences were observed between treatments $(\mathrm{P}>0.05)$, which could be due to the fact that the pre-slaughtering management, level of glycogen and level of stress to which the chickens were subjected were similar for all treatments.

The drip loss can be considered of high economic and productive importance due to the weight loss of the meat that takes place during storage, which affects meat quality (LealGutiérrez et al., 2015). In breast meat, drip loss varied between $1.25 \%$ and $1.74 \%$ (Table 3 ), without significant differences among treatments $(P>0.05)$. Generally, drip loss increases in smaller cuts and is almost null in the carcasses. Once the cutting has been carried out, drip loss is around $1 \%$ after two days of chilling. When the meat is cut in steaks or cubes, drip loss increases between $2 \%$ and $6 \%$ of the weight of lean meat after four days under refrigeration (Morón-Fuenmayor and Zamorano, 2004).

Color parameters of chicken meat are shown in Table 4. In breast meat, there were no significant differences in parameters $L^{*}, a^{*}, b^{*}$ and $C^{*}(P>0.05)$ between treatments. No significant differences in parameters $a^{*}, b^{*}$ and $C^{*}(P>0.05)$ were found in thigh meat; however, a lower lightness $\left(\mathrm{L}^{*}\right)$ was observed in the treatments with higher concentration of vinasse (T3 and T4) compared to $\mathrm{T} 1$, without significant differences $(\mathrm{P}>0.05)$ with 
Table 3. Carcass yield, pH and drip loss of poultry meat of broiler chickens fed with chicory vinasse.

\begin{tabular}{cccccc}
\hline Treatment & $\begin{array}{c}\text { Feed intake } \\
\text { (g chicken day }^{-1} \text { ) }\end{array}$ & $\begin{array}{c}\text { Carcass yield } \\
\text { (Carcass weight }^{\text {(ive weight }} \text { - }^{\text {) }}\end{array}$ & $\mathbf{p H}_{\mathbf{0}}$ & $\mathbf{p H}_{24}$ & $\begin{array}{c}\text { Drip loss } \\
\text { (\%) }\end{array}$ \\
\hline T0 & $186.9 \mathrm{a}$ & $71.46 \mathrm{a}$ & $6.03 \mathrm{a}$ & $5.70 \mathrm{a}$ & $1.25 \mathrm{a}$ \\
$\mathrm{T} 1$ & $188.6 \mathrm{a}$ & $71.22 \mathrm{a}$ & $5.79 \mathrm{a}$ & $5.78 \mathrm{a}$ & $1.74 \mathrm{a}$ \\
$\mathrm{T} 2$ & $139.5 \mathrm{~b}$ & $59.86 \mathrm{~b}$ & $6.23 \mathrm{a}$ & $5.67 \mathrm{a}$ & $1.31 \mathrm{a}$ \\
$\mathrm{T} 3$ & $115.8 \mathrm{c}$ & $60.40 \mathrm{~b}$ & $6.15 \mathrm{a}$ & $5.66 \mathrm{a}$ & $1.40 \mathrm{a}$ \\
$\mathrm{T} 4$ & $97.8 \mathrm{~d}$ & $54.27 \mathrm{c}$ & $6.12 \mathrm{a}$ & $5.67 \mathrm{a}$ & $1.42 \mathrm{a}$ \\
CV & 6.77 & 4.89 & 3.96 & 2.43 & 8.27 \\
\hline
\end{tabular}

$\mathrm{pH}_{0}: \mathrm{pH}$ of the meat after slaughter; $\mathrm{pH}_{24}: \mathrm{pH}$ of the meat after 24 hours of slaughter; $\mathrm{CV}$ : Coefficient of variation (\%). Different letters in the same column indicate significant differences, according to Duncan's test $(\mathrm{P} \leq 0.05)$.

the control treatment. Qiao et al. (2002) indicated that color of the skin of broiler chickens, as well as the color of the meat are important attributes consumers use to select poultry products, and to purchase and evaluate the final quality. The main factors that contribute to the color of poultry meat are the myoglobin content, its reactions and the $\mathrm{pH}$ of the meat (Wattanachant, 2008). Myoglobin content is higher in thigh in comparison to breast (Cori et al., 2014), resulting in a higher a* (red) in thigh meat, and a higher $\mathrm{b}^{*}$ (yellow) in breast meat. Breast meat from T1 presented a hue angle (h) higher than in T2 and T4, whereas thigh meat from T1 presented a higher hue angle than T4 $(\mathrm{P}$ $\leq 0.05$ ), without significant differences with the control $(P>0.05)$. In this study, hue angle values were between $45^{\circ}$ (red) and $90^{\circ}$ (orange). Thus, the higher the value of the hue angle the closest to the orange color, as it happened in T1. The color differences could be noticed by the human eye when $\Delta \mathrm{E}$ is higher than 5 or 6 . Only expert people perceive $\Delta \mathrm{E}$ of 3 or 4 (LaCie, 2006). Therefore, in this study the differences in the color of meat from broiler chickens fed chicory vinasse respect to the control treatment would not be perceptible by consumers, as values between 1.72 and 3.94 for breast meat and 0.70 and 2.45 for thigh meat were obtained.

The results of composition of chicken meat are presented in Table 4. Nutritional composition of chicken meat is related to species, breed, type of muscle, sex, age, and treatment of carcasses (Wattanachant, 2008). The protein content of breast meat was higher than that of thigh meat, while the opposite occurred with the lipid content, as reported in other studies (Michel et al., 2015). There were no variations among treatments in the composition of breast meat $(\mathrm{P}$ $>0.05)$. However, significant differences $(P \leq 0.05)$ in thigh meat were found among treatments in terms of content of protein (CP), lipids (EE) and minerals (TA). Differences could be related to the weight gain of the animals, because a lower feed intake can not only affect carcass yield (Table 3), but also metabolism. A higher protein content and lower lipids content were determined in the thigh of $\mathrm{T} 4(\mathrm{P} \leq 0.05)$. Therefore, a leaner type of meat can be obtained by replacing $100 \%$ of soybean meal by chicory vinasse; however, smaller cuts are obtained due to the lower yield. Significant differences $(\mathrm{P} \leq 0.05)$ were observed in $\mathrm{CP}$ and $\mathrm{EE}$ between $\mathrm{T} 3$ and $\mathrm{T} 2$ and $\mathrm{T} 4$, which was not related to the feed intake. Therefore, metabolism could account for this situation, but further research is needed.

Appearance, flavor, aroma and texture of the meat can lead the decision of a consumer to purchase meat (Jayasena et al., 2013). The acceptance of color/appearance, flavor and total acceptance of chicken meat had a score between 3 (indifferent) and 4 (I like it) (Table 5). However, no significant differences $(\mathrm{P}>0.05)$ were observed in acceptance of the sensory characteristics of the meat between treatments. Therefore, the replacement of soybean meal for chicory vinasse in the diets of broiler chickens may not affect the sensory characteristics. However, the sensory panel had no prior training because the aim was to obtain a general acceptance evaluation and, therefore, specific sensorial characteristics were not evaluated.

\section{CONCLUSIONS}

The carcass yield decreases as the content of chicory vinasse increases as a replacement of soybean meal in the diet of broiler chickens. Meat quality parameters, such as $\mathrm{pH}$, drip loss and acceptance showed no variation with the addition of chicory vinasse in the diets. However, there are differences in the nutritional composition and lightness of the meat, specifically in thigh, with the total replacement of the soybean meal for chicory vinasse in the diet. 
Table 4. Color parameters and nutritional composition of breast and thigh of broiler chickens fed with chicory vinasse.

\begin{tabular}{|c|c|c|c|c|c|c|c|c|c|}
\hline & \multicolumn{6}{|c|}{ Color parameters } & \multicolumn{3}{|c|}{ Nutritional composition } \\
\hline Treatment & $\mathbf{L}^{*}$ & $a^{*}$ & $\mathbf{b}^{*}$ & $\mathrm{C}^{*}$ & $\mathbf{h}$ & $\Delta \mathrm{E}$ & $\mathrm{CP}^{¥}$ & $\mathrm{EE}^{¥}$ & TA $^{*}$ \\
\hline \multicolumn{10}{|c|}{ Breast } \\
\hline T0 & $58.26 \mathrm{a}$ & $5.94 \mathrm{a}$ & $16.94 \mathrm{a}$ & $17.96 \mathrm{a}$ & $70.63 \mathrm{ab}$ & - & $81.94 \mathrm{a}$ & $6.68 \mathrm{a}$ & $5.32 \mathrm{a}$ \\
\hline $\mathrm{T} 1$ & $61.97 \mathrm{a}$ & $5.71 \mathrm{a}$ & $18.26 \mathrm{a}$ & $19.13 \mathrm{a}$ & $72.69 \mathrm{~b}$ & 3.95 & 86.74 a & $5.63 \mathrm{a}$ & $4.95 \mathrm{a}$ \\
\hline $\mathrm{T} 2$ & $59.25 \mathrm{a}$ & $7.22 \mathrm{a}$ & $17.92 \mathrm{a}$ & $19.32 \mathrm{a}$ & 68.15 a & 1.89 & $81.35 \mathrm{a}$ & $6.87 \mathrm{a}$ & $4.85 \mathrm{a}$ \\
\hline T3 & $58.92 \mathrm{a}$ & $7.00 \mathrm{a}$ & $19.53 \mathrm{a}$ & $20.75 \mathrm{a}$ & $70.46 \mathrm{ab}$ & 2.87 & 86.99 a & $6.18 \mathrm{a}$ & $5.04 \mathrm{a}$ \\
\hline $\mathrm{T} 4$ & $58.59 \mathrm{a}$ & $7.52 \mathrm{a}$ & $17.54 \mathrm{a}$ & $19.11 \mathrm{a}$ & $66.72 \mathrm{a}$ & 1.73 & 83.40 a & $2.83 \mathrm{a}$ & $5.09 \mathrm{a}$ \\
\hline $\mathrm{CV}$ & 3.53 & 15.70 & 11.48 & 11.44 & 3.19 & & 6.28 & 28.94 & 7.62 \\
\hline \multicolumn{10}{|c|}{ Thigh } \\
\hline T0 & $60.19 a b$ & $7.00 \mathrm{a}$ & $12.26 \mathrm{a}$ & $14.14 \mathrm{a}$ & $59.90 \mathrm{ab}$ & - & $62.82 \mathrm{~b}$ & $32.24 \mathrm{c}$ & $3.89 \mathrm{a}$ \\
\hline $\mathrm{T} 1$ & $62.45 \mathrm{~b}$ & $6.07 \mathrm{a}$ & $12.49 \mathrm{a}$ & $13.89 \mathrm{a}$ & $64.35 \mathrm{~b}$ & 2.46 & $61.88 \mathrm{ab}$ & $33.26 \mathrm{c}$ & $3.87 \mathrm{a}$ \\
\hline $\mathrm{T} 2$ & $59.85 \mathrm{ab}$ & $7.43 \mathrm{a}$ & $12.70 \mathrm{a}$ & $14.74 \mathrm{a}$ & $59.50 \mathrm{ab}$ & 0.70 & $63.78 \mathrm{~b}$ & $25.42 \mathrm{~b}$ & $4.04 \mathrm{ab}$ \\
\hline T3 & $58.89 \mathrm{a}$ & $8.06 \mathrm{a}$ & 13.13 a & $15.42 \mathrm{a}$ & $58.55 \mathrm{ab}$ & 1.89 & $59.63 \mathrm{a}$ & $33.52 \mathrm{c}$ & $3.96 \mathrm{ab}$ \\
\hline $\mathrm{T} 4$ & $58.73 \mathrm{a}$ & $7.03 \mathrm{a}$ & 10.34 a & $12.58 \mathrm{a}$ & 54.61 a & 2.40 & $75.59 \mathrm{c}$ & $14.21 \mathrm{a}$ & $4.67 \mathrm{~b}$ \\
\hline $\mathrm{CV}$ & 2.07 & 14.41 & 19.52 & 16.85 & 7.47 & & 4.92 & 18.09 & 7.01 \\
\hline
\end{tabular}

L*: Luminosity; a*: Green-Red; b*: Blue-Yellow; C*: Chroma; h: Hue angle; $\triangle E$ : Color difference; CV: Coefficient of variation (\%). Nutritional composition. Values expressed in percentage. ¥ Dry matter based; CP: Crude protein; EE: Ether extract; TA: Total ash.

Different letters for each meat cut in the same column indicate significant differences, according to Duncan's test $(\mathrm{P} \leq 0.05)$.

Table 5. Acceptance (median) of poultry meat of broiler chickens fed with chicory vinasse.

\begin{tabular}{cccc}
\hline Treatment & Color/Appearance & Flavor & Total acceptance \\
\hline T0 & $3 \mathrm{a}$ & $3 \mathrm{a}$ & $3 \mathrm{a}$ \\
T1 & $4 \mathrm{a}$ & $3 \mathrm{a}$ & $4 \mathrm{a}$ \\
T2 & $4 \mathrm{a}$ & $3 \mathrm{a}$ & $4 \mathrm{a}$ \\
T3 & $4 \mathrm{a}$ & $3 \mathrm{a}$ & $4 \mathrm{a}$ \\
T4 & $3 \mathrm{a}$ & $3 \mathrm{a}$ & $3 \mathrm{a}$ \\
\hline
\end{tabular}

Non-parametric analysis of variance Kruskal-Wallis. Different letters in the same column indicate significant differences, according to Conover test $(\mathrm{P} \leq 0.05)$.

\section{ACKNOWLEDGMENTS}

This study was financed by the DIUC Project 213.121.015-1.0 and the Company Beneo Orafti Chile S.A.

\section{LITERATURE CITED}

AOAC. 1997. Official methods of analysis. AOAC International. Volume II. (16th. ed.). AOAC International, Gaithersburg, USA.

Arístegui, J.P. 2009. Los biocombustibles desde la perspectiva del comercio internacional y del derecho de la organización mundial del comercio. Rev. Derecho (Valdivia) 22(1):113134.
Beriain, M.J., P. Bas, A. Purroy, and T. Treacher. 2000. Effect of animal and nutritional factors and nutrition on lamb meat quality. p. 75-86. In Ledin, I., Morand-Fehr, P. (eds.). Sheep and goat nutrition: intake, digestion, quality of products and rangelands. Cahiers Options Méditerranéennes $\mathrm{N}^{\circ}$ 52. IAMZ-CIHEAM. Zaragoza, Spain.

Cori, M.E., C. Michelangeli, V. De Basilio, R. Figueroa, y N. Rivas. 2014. Solubilidad proteica, contenido de mioglobina, color y $\mathrm{pH}$ de la carne de pollo, gallina y codorniz. Arch. Zootec. 63(241):133-143.

Díaz, M.F., C. Padilla, V. Torres, A. González, y A. Noda. 2003. Caracterización bromatológica de especies y variedades de leguminosas temporales con posibilidades en la alimentación animal. Rev. Cuba. Cienc. Agríc. 37(4):453-457. 
Estrada-Pareja, M.M., S-M. Márquez-Girón, y L.F. Restrepo. 2007. Efecto de la temperatura y la humedad relativa en los parámetros productivos y la transferencia de calor en pollos de engorde. Rev. Colomb. Cienc. Pec. 20(3):288-303.

Giacomozzi, J. 2015. Actualización del mercado avícola. Oficina de Estudios y Políticas Agrarias ODEPA. Ministerio de Agricultura. Gobierno de Chile. Julio 2014. Disponible en http://www.odepa.cl/wp-content/files $\mathrm{mf} / 1431462062$ Aves20152015.05.12.pdf (Consulta 03 enero 2018).

James, C., C. Vincent, T.I. De Andrade Lima, and S.J. James. 2006. The primary chilling of poultry carcasses: a review. Int. J. Refrigeration 29:847-862.

Jayasena, D., D.U. Ahn, K.Ch. Nam, and Ch. Jo. 2013. Flavour chemistry of chicken meat: a review. Asian Australas. J. Anim. Sci. 26(5):732-742.

Jiang, S.Q., Z.Y. Jiang, G.L. Zhou, Y.C. Lin, and C.T. Zheng. 2014. Effects of dietary isoflavone supplementation on meat quality and oxidative stability during storage in lingnan yellow broilers. J. Integr. Agric. 13(2):387-393.

Konica Minolta. 2003. Comunicación precisa del color. Control del color: de percepción a instrumentación. Disponible en http:// sensing.konicaminolta.com.mx/learningcenter/color-measurement/colorbasics.pdf (Consulta 03 enero 2018).

LaCie. 2006. Libro blanco de la gestión del color. 3. Espacios de color y conversión de colores. LaCie, 22985 NW Evergreen Parkway, Hillsboro, OR 97124 EE.UU. LaCie Group, 17 rue Ampère 91349 Massy Cedex FRANCIA. Disponible en https://mediatecnicaeo.files. wordpress.com/2012/02/la-cie-com31.pdf (Consulta 03 enero 2018).

Leal-Gutiérrez, J.D.,L.M. Jiménez-Robayo, M. Ariza, C. Manrique, J. López, C. Martínez, et al. 2015. Polimorfismos de los genes CAPN1, CAST, DES, PRKAG3 y RYR1 asociados a la capacidad de retención de agua en crudo y cocinado en carne de bovino en cruces Bos indicus y Bos taurus en Colombia. Arch. Zootec. 64(245):29-35.

Michel, M.A., R. Fernández, F. Revidatti, M. Sindik, y P. Sanz. 2015. Propiedades físicoquímicas y tecnológicas de la carne en dos genotipos de pollos de crecimiento lento. Rev. Vet. 26(2):131-135.

Monroe, A., K.S. Latimer, G.M. Pest, and R.I. Bakalli. 2003. Pathology and histology of dietary tryptophan deficiency in broiler chickens. Avian Dis. 47(4):1393-1398
Morón-Fuenmayor, O.E., y L. Zamorano. 2004. Pérdida por goteo en carne cruda de diferentes tipos de animales. Revista Científica FCV-LUZ 14(1):36-39.

NRC. 1994. Nutrient requirements of poultry. p. 1-176. 9th. ed. National Research Council (NRC), National Academy Press, Washington D.C., USA.

ODEPA. 2016. Precios: series de tiempo del rubro leguminosas. Oficina de Estudios y Políticas Agrarias, Chile. Disponible en http://www. odepa.gob.cl/rubro/leguminosas/ (Consulta 03 enero 2018).

Otto, G., R. Roehe, H. Looft, L. Thoelking, and E. Kalm. 2004. Comparison of different methods for determination of drip loss and their relationships to meat quality and carcass characteristics in pigs. Meat. Sci. 68(3):401-409.

Qiao, M., D.L. Fletcher, J.K. Northcutt, and D.P. Smith. 2002. The relationship between raw broiler breast meat color and composition. Poultry Sci. 81:422-427.

Temprado, R.M. 2005. Calidad de la carne de pollo. Selecciones Avícolas 47(6):347-355.

Traub, A.J. 2014. Achicoria: precursora de la inulina. Oficina de Estudios y Políticas Agrarias (ODEPA). Disponible en http://www.odepa.cl/wp-content/files_ mf/1406041829Inulina201407.pdf. (Consulta 03 enero 2018).

Trómpiz, J., M.J. Villamide, A. Ferrer, L. Arenas, N. Jerez, y L. Sandoval. 2010. Dietas con follaje de yuca y su efecto sobre las características al sacrificio y rendimiento en canal y en cortes de pollos de engorde. Revista Científica FCVLUZ 20(3):293-299.

Velasco, V., C. Orellana, P. Williams, J. Campos, y P. Melín. 2011. Parámetros de calidad de carne de caprinos alimentados con dieta suplementada con orégano (Origanum vulgare L.) seco. Agro-Ciencia 27(2):95-104.

Wattanachant, S. 2008. Factors affecting the quality characteristics of thai indigenous chicken meat. Suranaree. J. Sci. Technol. 15(4):317-322. 